\title{
Reversed flow events in the cusp ionosphere detected by SuperDARN HF radars
}

\author{
K. Oksavik, ${ }^{1,2}$ J. I. Moen, ${ }^{2,3}$ E. H. Rekaa, ${ }^{3}$ H. C. Carlson, ${ }^{4}$ and M. Lester ${ }^{5}$ \\ Received 27 April 2011; revised 24 August 2011; accepted 22 September 2011; published 3 December 2011.
}

[1] We present several examples of reversed flow events (RFEs) from the cusp

ionosphere. RFEs are 100-200 km wide flow channels opposing the background plasma convection. RFEs were discovered a few years ago by the incoherent scatter European Incoherent Scatter Svalbard Radar. In this paper we show that coherent scatter Super Dual Auroral Radar Network (SuperDARN) HF radars can also see RFEs. We report a close relationship between RFEs and the development of HF backscatter power and spectral width. Wide spectra were seen near the edges of the RFEs (i.e., associated with the flow shear), and there was a significant increase in SuperDARN HF backscatter power when the RFE expanded. This increase in power is much faster than anticipated from the gradient drift instability alone, supporting the hypothesis that RFE flow shears foster rapid growth of Kelvin-Helmholtz instabilities. That decameter-scale irregularities form so rapidly should be an important guide to the development of instability theory for cascade of plasma irregularities from larger to smaller scale sizes.

Citation: Oksavik, K., J. I. Moen, E. H. Rekaa, H. C. Carlson, and M. Lester (2011), Reversed flow events in the cusp ionosphere detected by SuperDARN HF radars, J. Geophys. Res., 116, A12303, doi:10.1029/2011JA016788.

\section{Introduction}

[2] The primary transfer mechanism of flux from the solar wind to the magnetosphere is believed to be impulsive dayside reconnection and flux transfer events (FTEs) [Cowley and Lockwood, 1992; Lockwood et al., 1995]. FTEs were first discovered at the magnetopause by Haerendel et al. [1978] and Russell and Elphic [1978, 1979], with typical scale sizes of one Earth radius in the boundary normal direction [Saunders et al., 1984], corresponding to around $100-200 \mathrm{~km}$ along the meridian in the ionosphere [Southwood, 1985, 1987]. A burst of reconnection is believed to propagate from the magnetopause to the ionosphere as an Alfvénic disturbance with an associated system of field-aligned Birkeland currents [Glassmeier and Stellmacher, 1996]. For this reason, poleward-moving transients in the dayside aurora have often been interpreted as a signature of FTEs [Sandholt et al., 1990, 1993; Denig et al., 1993; Milan et al., 1999, 2000; Thorolfsson et al., 2000]. The first radar observations of FTE signatures in the ionosphere were presented by van Eyken et al. [1984] and Goertz et al. [1985]. Later there have been frequent reports of

\footnotetext{
${ }^{1}$ Department of Physics and Technology, University of Bergen, Bergen, Norway.

${ }^{2}$ The University Centre in Svalbard, Longyearbyen, Norway.

${ }^{3}$ Department of Physics, University of Oslo, Oslo, Norway.

${ }^{4}$ Space Weather Center, Center for Atmospheric and Space Sciences, Utah State University, Logan, Utah, USA.

${ }^{5}$ Department of Physics and Astronomy, University of Leicester, Leicester, UK

Copyright 2011 by the American Geophysical Union. 0148-0227/11/2011JA016788
}

poleward-moving transients, which depending on their unique characteristics, have been called flow channel events (FCEs) [Pinnock et al., 1993, 1995; Chisham et al., 2000; Neudegg et al., 1999, 2000], pulsed ionospheric flows (PIFs) [Provan et al., 1998, 2002; Provan and Yeoman, 1999; McWilliams et al., 2000], or poleward-moving radar auroral forms (PMRAFs) [Milan et al., 2000; Davies et al., 2002; Rae et al., 2004]. Sandholt et al. [2004] described three types of flow channels that are found in connection with daytime aurora: (1) Enhanced sunward return flow on closed field lines [Lockwood et al., 1993; Moen et al., 1995, 2006], (2) enhanced flow on newly open flux containing FTEs (FCEs and PIFs), and (3) enhanced flow on old open field lines due to the solar wind magnetosphere dynamo in the high-latitude boundary layer [Stern, 1984; Sandholt et al., 2004; Farrugia et al., 2004; Sandholt and Farrugia, 2007]. All three types give enhanced flow in the same direction as the classical large-scale flow pattern in the polar cap.

[3] Recently, a new and fourth category of enhanced plasma flow was reported [Rinne et al., 2007; Moen et al., 2008]. Rinne et al. [2007] called this phenomenon a reversed flow event (RFE), because the enhanced flow was in the opposite direction of the background convection; that is, reversing the flow. In the last decade there have been several publications using high-resolution European Incoherent Scatter (EISCAT) Svalbard Radar (ESR) measurements to study flow channels in the cusp region [Carlson et al., 2004; Oksavik et al., 2004b, 2005; Rinne et al., 2007, 2010; Moen et al., 2008]. Carlson et al. [2004] focused on ionospheric signatures of magnetic reconnection flow jets, while the other authors investigated flow shears and currents in the vicinity of poleward-moving auroral forms. According 
to the definition of Rinne et al. [2007], the flow speed inside the RFE channel must be $>250 \mathrm{~m} / \mathrm{s}$ for the event to qualify as an RFE. The reason for this criterion was to focus on events that are significant and that clearly stand out from the large-scale background convection; that is, if the background convection is $>250 \mathrm{~m} / \mathrm{s}$ in one direction, the flow speed inside the RFE channel must be $>250 \mathrm{~m} / \mathrm{s}$ in the other direction, corresponding to a net flow shear $>500 \mathrm{~m} / \mathrm{s}$, which is significant. RFEs can persist for 10-20 min [Moen et al., 2008], and, within one hour of magnetic noon, Rinne et al. [2007] observed RFEs $40 \%$ of the time, with no apparent preference to interplanetary magnetic field (IMF) $B_{Y}$ or $B_{Z}$ polarity, but with a clear preference for clock angles between $40^{\circ}$ and $240^{\circ}$, that is, $\left|B_{Y}\right|>\left|B_{Z}\right|$. Polewardmoving transients in the dayside aurora are frequent in this clock angle regime, and Oksavik et al. [2004b, 2005] have also related the flow vorticity around these events to the location of auroral emissions. Oksavik et al. found that the clockwise vorticity on one side of the flow channel is consistent with an upward Birkeland current (i.e., intense aurora), while counterclockwise vorticity on the other side of the flow channel is consistent with a downward Birkeland current (i.e., weak aurora). Consequently, if we have an eastward directed RFE flow channel embedded in a region of large-scale westward flow, the RFE channel will be located on the poleward side of the discrete aurora, near the clockwise flow reversal, consistent with a Birkeland Current Arc (BCA) [Moen et al., 2008]. According to Moen et al. [2008], the RFE phenomenon does not appear to be uniquely related to PMAFs, but, rather, it appears to be a specific feature of BCAs. Moen et al. [2008] provide two possible explanations for the generation of RFEs: (1) the RFE channel may be a region where two magnetosphereionosphere (MI) current loops, forced by independent voltage generators, couple through a poorly conducting ionosphere, or (2) the RFE channel may be the ionospheric footprint of an inverted-V-type coupling region. It is still unclear if one of the two mechanisms dominates, or if both mechanisms are closely related.

[4] The existence of RFE channels may have important implications for the production of plasma irregularities as well, including decameter-scale irregularities that produce backscatter in HF coherent scatter (CS) observations with the Super Dual Auroral Radar Network (SuperDARN) radars. However, to our knowledge examples of RFE channels have never been reported in SuperDARN data, perhaps due to the coarser resolution of traditional gridded SuperDARN convection maps (i.e., $110 \mathrm{~km} \times 110 \mathrm{~km}$ ), and the typical orientation of these radars relative to most RFEs. The majority of SuperDARN HF radar beams are aligned closer to the magnetic meridian, while the experience from Rinne et al. [2007] and Moen et al. [2008] is that the maximum flow of RFEs is typically in the east-west direction, giving preference to radar beams looking in the zonal direction. For CS radar observations in the HF band, like SuperDARN, it is necessary that plasma irregularities are generated in the volume of study. To be able to detect these irregularities the radar must operate at a frequency that allows a successful refraction of the HF radio wave by the ionosphere to achieve orthogonality with Earth's magnetic field. This can be achieved via one single forward refraction of the radio wave in the ionosphere (e.g., 0.5F mode backscatter), or multiple ionosphere-ground reflections that brings the transmitted signal far beyond the horizon (e.g., $1.5 \mathrm{~F}$ or $2.5 \mathrm{~F}$ mode backscatter). For a radio wave raypath to be successful, the signal must also avoid any absorption in the ionosphere (e.g., severe ionization in the $D$ region due to solar proton events). Incoherent scatter (IS) observations like EISCAT rely on large antenna aperture, powerful transmitters, lownoise receivers, and advanced coding of the transmitted UHF signal to obtain weak echoes from electrons in the ionosphere. The shape of the backscatter spectrum can be used to derive parameters like the electron density, electron/ ion temperature, and line-of-sight Doppler velocity of ions. IS radars can only make measurements at least far enough above the local horizon to avoid ground clutter from antenna sidelobes (for the ESR it is at least $30^{\circ}$ above the local horizon). Ground clutter can also be a constraint for CS HF radars, for example, the shaded areas in Figure 2. The spatial resolution offered by IS radars is often far superior to other radar techniques. In the studies of Rinne et al. [2007] and Moen et al. [2008] the spatial resolution of the ESR IS data was only $15 \mathrm{~km} \times 30 \mathrm{~km}$. For a CS radar such as SuperDARN the range resolution is typically $15-45 \mathrm{~km}$, but the azimuthal beam width varies with transmitter frequency from $\sim 3.5^{\circ}$ at $15 \mathrm{MHz}$ to $\sim 5^{\circ}$ at $10 \mathrm{MHz}$, corresponding to $60-90 \mathrm{~km}$ at $1000 \mathrm{~km}$ ground range and more than $180-260 \mathrm{~km}$ at $3000 \mathrm{~km}$ ground range, respectively.

[5] However, the observation of enhanced HF backscatter is common for the cusp ionosphere [Baker et al., 1990; Milan et al., 1998]. The equatorward edge of the HF radar cusp is usually defined by broad multipeak Doppler spectra [Baker et al., 1990] and/or by enhanced backscatter power [Rodger et al., 1995; Yeoman et al., 1997; Milan et al., 1999]. Rodger et al. [1995] reported that the equatorward edge of the optical cusp and the HF radar cusp were colocated to better than $1^{\circ}$ in latitude. This result was later confirmed in other studies [e.g., Milan et al., 1999; Moen et al., 2000; Oksavik et al., 2004a], but it is not entirely clear why there is such a latitude offset, or the exact location of the HF backscatter relative to the aurora. Moen et al. [2000] found the two boundaries to follow each other intimately in 2-D, which indicates a very efficient production mechanism of decameter backscatter targets. The gradient drift (GD) plasma instability has often been regarded as the dominant mode for the production of electron density irregularities in the $F$ region cusp [Ossakow and Chaturvedi, 1979; Keskinen and Ossakow, 1983; Tsunoda, 1988; Basu et al., 1988, 1990, 1994, 1998; Gondarenko and Guzdar, 2004]. The GD plasma instability mechanism is known to occur for plasma drift, of the correct sign, across a steep plasma density gradient perpendicular to the Earth's magnetic field at high latitudes [Keskinen and Ossakow, 1983]. Plasma drift in the opposite direction will set up polarization fields that stabilize the plasma against any irregularity formation. An alternative mechanism is the velocity shear Kelvin-Helmholtz (KH) driven plasma instability, which is expected to occur if there are severe velocity shears in the plasma [Basu et al., 1988, 1990]. Keskinen et al. [1988] developed the theory to describe these $\mathrm{KH}$ instabilities, and they also included a refinement of ionospheric-magnetospheric electrical coupling. The rapid growth of irregularities seen by SuperDARN HF radars, however, is hard to explain using the GD mechanism alone [Moen et al., 2002]. Carlson et al. [2007] 
presented a series of five velocity shears, transforming corotating subauroral plasma into five new patches inserted into the transpolar flow pattern. They also demonstrated that the observed growth of irregularities in SuperDARN HF radar data had an observed onset time of minutes, much faster than possible from linear theory and the GD instability alone (>10 min [Moen et al., 2002]), but well matching that calculated from KH linear instability theory $(<1$ min [Carlson et al., 2007]). Carlson et al. [2007, 2008] thus proposed that the GD mechanism could act together with the shear driven KH instability. They concluded that the initial patch structuring (first 10-15 min) is driven by KH, not GD, while GD would sustain patch structuring later downstream in the polar cap. Carlson et al. [2008] summarized patch formation and structuring down to kilometer scales by reconnection shears, and suggested that SuperDARN HF radars could test theories of irregularity cascade down to decameter-scale lengths (e.g., by monitoring the development of key parameters like the backscatter power from irregularities, the mesoscale flow shears in the vicinity of irregularities, and changes in the overall plasma flow in a large area of the cusp).

[6] In this paper we report RFEs seen by a SuperDARN HF radar, we will compare radar and optical data to test the accuracy of the SuperDARN range determination algorithm, and we will demonstrate a close relationship between the development of RFEs and increased levels of HF backscatter power, supportive of the two-step irregularity production process of Carlson et al. [2007, 2008].

\section{Data Presentation}

[7] Figure 1 presents an overview of the solar wind parameters at 08:30 to 09:30 UT on 20 December 2001 from the ACE spacecraft. The data have been time shifted by $70 \mathrm{~min}$ to account for the solar wind propagation delay from the spacecraft location $\left(\mathrm{X}_{\mathrm{GSM}}=240 R_{E}, \mathrm{Y}_{\mathrm{GSM}}=25 R_{E}, \mathrm{Z}_{\mathrm{GSM}}=\right.$ $7 R_{E}$ ) to the dayside magnetopause. All parameters were fairly stable. The solar wind density was around $3 \mathrm{~cm}^{-3}$ and the solar wind speed was around $375 \mathrm{~km} / \mathrm{s}$. The interplanetary magnetic field (IMF) was characterized by a negative $B_{Z}(-3 \mathrm{nT})$, a positive $B_{Y}(2-4 \mathrm{nT})$, a negative $B_{X}(-3 \mathrm{nT})$, and a clock angle in the range $110^{\circ}-160^{\circ}$. The dashed line in Figure 1g shows that the SuperDARN HF radars had wide coverage with around 600-800 data points in the mappotential model [Ruohoniemi and Baker, 1998], and the polar cap potential (solid line in Figure 1g) was fairly stable around 50-80 kV. Indicated in Figure 1, with vertical red guide lines, are three RFE intervals to be studied in more detail.

[8] Figure 2 shows the large-scale convection pattern as indicated by the contour lines from the SuperDARN mappotential model (solid and dashed black lines). The convection pattern was created by using the technique of Ruohoniemi and Baker [1998]. The particular image is from 09:09 UT (i.e., the third RFE event). However, due to the stable IMF situation, the flow pattern is representative of the entire interval of study. Figure 2 also shows one scan from the Hankasalmi, Finland, radar. The Hankasalmi radar was operating in a fast common mode, with a scan period of $48 \mathrm{~s}$ (see Chisham et al. [2007] for a full description of
SuperDARN). The radar frequency was $12.3 \mathrm{MHz}$, corresponding to $\sim 12 \mathrm{~m}$ backscatter targets (half the radar wavelength). The horizontal dimension of a range cell over Svalbard was $45 \mathrm{~km} \times 150 \mathrm{~km}\left(300 \mu\right.$ s pulse length, $3.2^{\circ}$ azimuthal beam width). The Hankasalmi radar covered the postnoon inflow region, consistent with a duskward shift of the ionospheric cusp under a condition of IMF $B_{Y}$ positive [e.g., Cowley et al., 1991; Newell et al., 2004]. In Figure 2, positive line-of-sight velocity (toward the radar site) is colored blue, and negative velocity (away from the radar site) is colored red-orange and shading is used to indicate backscatter from the ground. The red RFE channel is $150 \mathrm{~km}$ wide and embedded in an area of westward background flow (blue). It is a prominent example of the RFE defined by Rinne et al. [2007]. As shown, the feature is too narrow to be resolved in the large-scale convection pattern resulting from the map-potential analysis.

[9] Figure 3 shows the intensity of the $630 \mathrm{~nm}$ electron aurora from the UiO imager in Ny-Ålesund, projected to an assumed emission altitude of atomic oxygen of $250 \mathrm{~km}$ (Figure 3, top row), and Hankasalmi radar data of line-ofsight Doppler velocity, backscatter power, and spectral width (Figure 3, bottom three rows) at three times 08:48, 08:58 and 09:09 UT. These events first appeared at 08:46, 08:56, and 09:07 UT, respectively (data not shown). There is one column per event, and the data are plotted in a magnetic grid with noon downward. Unfortunately, the SuperDARN pykkvibær radar had poor coverage over Svalbard, Norway, so only data from the Hankasalmi radar are available. To ease the comparison, in each column the location of the RFE flow channel is indicated with a solid black line. We have also added plus and minus symbols to indicate range gates where the line-of-sight Doppler velocity was positive (toward the radar) and negative (away from the radar). All three examples show that the RFE flow channel is a distinct feature embedded within the background flow, in an area of generally enhanced backscatter power and broad Doppler spectral width. The association of high backscatter power, large spectral widths, and bright $630.0 \mathrm{~nm}$ aurora is a characteristic feature of the cusp ionosphere [Baker et al., 1990; Yeoman et al., 1997; Milan et al., 1999; Moen et al., 2000; Oksavik et al., 2004a].

[10] The careful reader will notice that in Figure 3 there is a small misalignment between the radar data and the aurora (the RFE channel is located a few range gates poleward of the discrete aurora). Although our assumption for the red line emission height of $250 \mathrm{~km}$ may, in principle, be incorrect, it is unlikely to change the relative locations of the radar echoes and the auroral events significantly. However, the standard algorithm that is used to determine the ground range of SuperDARN HF backscatter echoes is associated with uncertainty [e.g., Yeoman et al., 2001]. We do not know the exact path of the radio wave, and we do not know the meridional electron density profile, which is important when irregularities are projected onto the geographical map [Villain et al., 1985]. If the virtual height assumption of HF propagation to the irregularity layer is inaccurate then the irregularities will be shifted in ground range, but the observed pattern will be preserved. We discuss this issue in more detail later (in section 3.2), but first we will present the time development of the radar data. 
20 December 2001

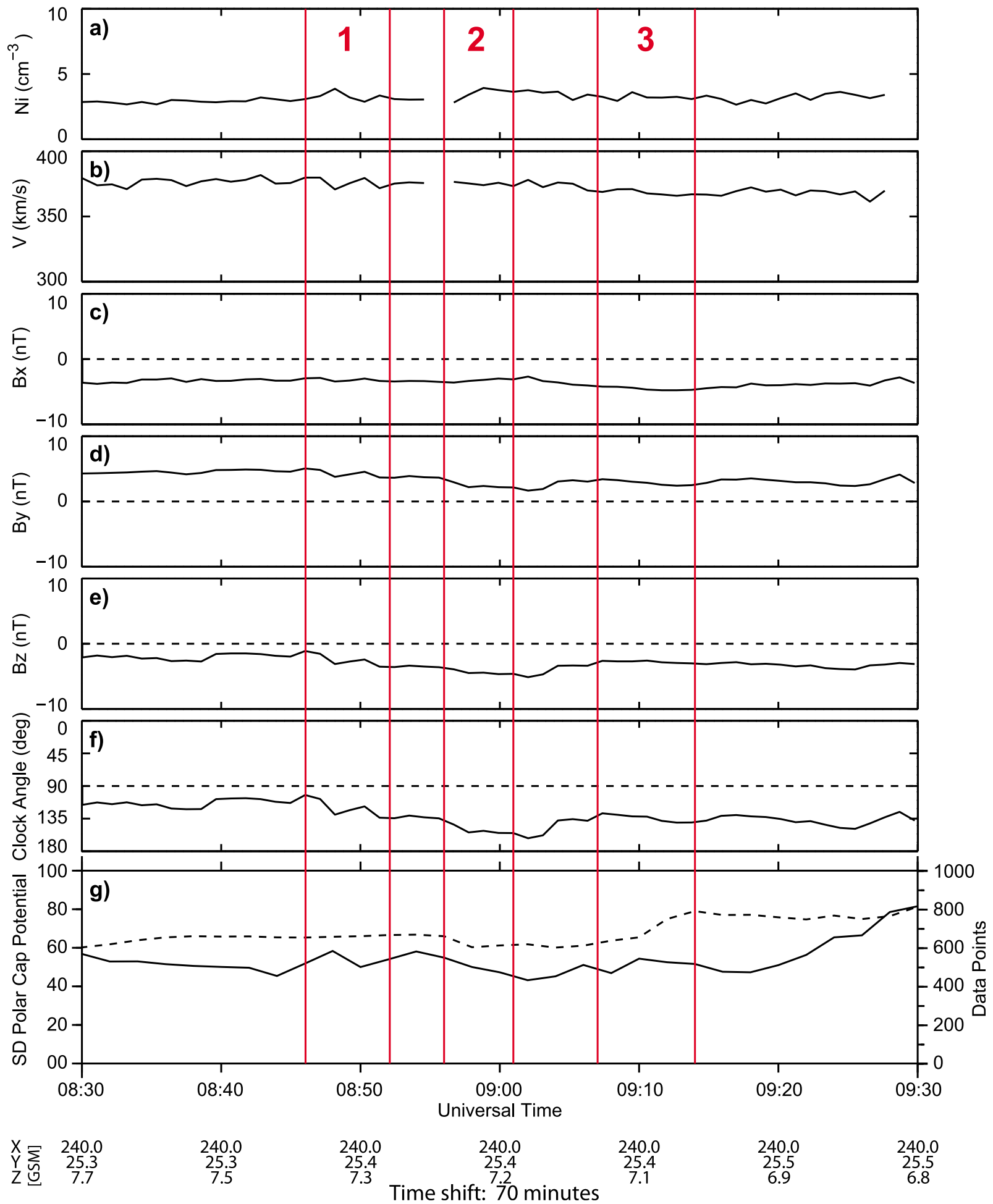

Figure 1. An overview of solar wind parameters from the ACE spacecraft from 08:30 to 09:30 UT on 20 December 2001. The ACE data has been time shifted by $70 \mathrm{~min}$ to account for the solar wind propagation delay from the spacecraft location to the dayside magnetopause. The times of three events to be studied in this paper are indicated with vertical red guide lines. The panels show (a) solar wind density, (b) solar wind speed, the interplanetary magnetic field (c) $B_{X}$, (d) $B_{Y}$, and (e) $B_{Z}$ components in GSM coordinates, (f) clock angle, and (g) the number of data points in the SuperDARN mappotential model for the Northern Hemisphere (dashed line) and the polar cap potential (solid line). Note that the situation for all three events is fairly stable, with $B_{Y}$ positive and $B_{Z}$ negative. 


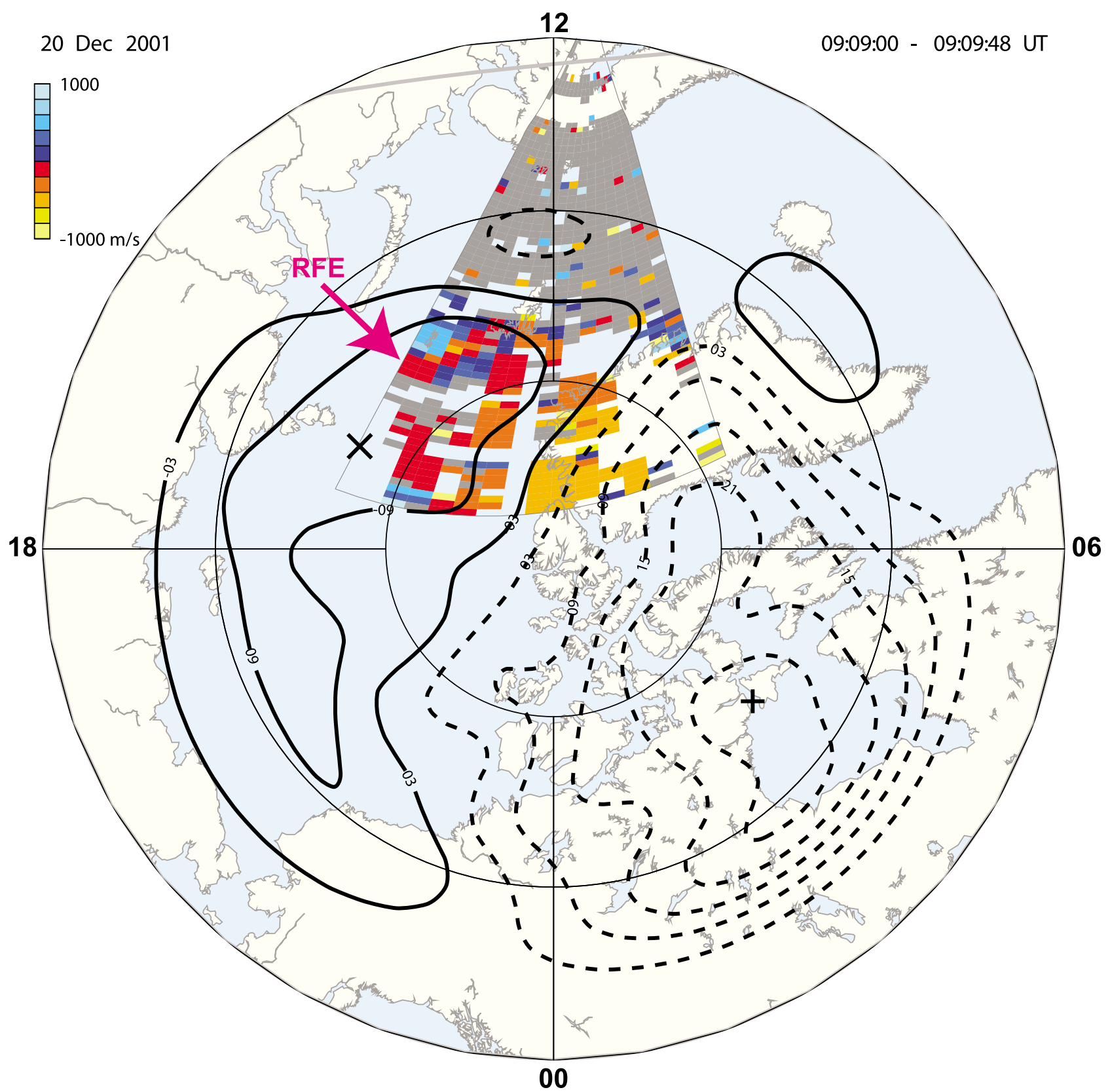

Figure 2. The large-scale flow pattern as indicated by contour lines from the SuperDARN map-potential model (plotted as solid and dashed black lines). We have also included an example of a Reversed Flow Event (RFE) seen by a SuperDARN HF radar in the postnoon sector. The narrow RFE flow channel (red color) is located in an area of sunward flow (blue color). Shading is used to indicate backscatter from the ground.

[11] In Figure 3 we have also highlighted, with pink guide lines, beam 13 of the Hankasalmi radar which intersects the RFE channel. Figure 4 shows backscatter power, spectral width, line-of-sight Doppler velocity, and the intensity of the $630 \mathrm{~nm}$ aurora from the UiO imager in Ny-Ålesund from 08:40 to 09:20 UT along this beam. The RFE channel is shown in Figure 4c. The large-scale background flow is shown in blue color (i.e., toward the radar and westward), and the RFE channel is identified in red (i.e., flow away from the radar and eastward). Solid black lines mark the equatorward boundary of the RFE or the transition from negative to positive flow velocities (i.e., clockwise vorticity). Dashed black lines mark the poleward boundary or the transition from positive to negative velocities (i.e., counterclockwise vorticity). Vertical shaded guide lines show where the examples in Figure 3 fit into the longer data set, and we note that the first two RFEs belonged to an interval of continuous activity, while the last RFE was an isolated event. 
NYA ASI: 20 Dec 2001, 084820 UT NYA ASI: 20 Dec 2001, 085820 UT NYA ASI: 20 Dec 2001, 090920 UT
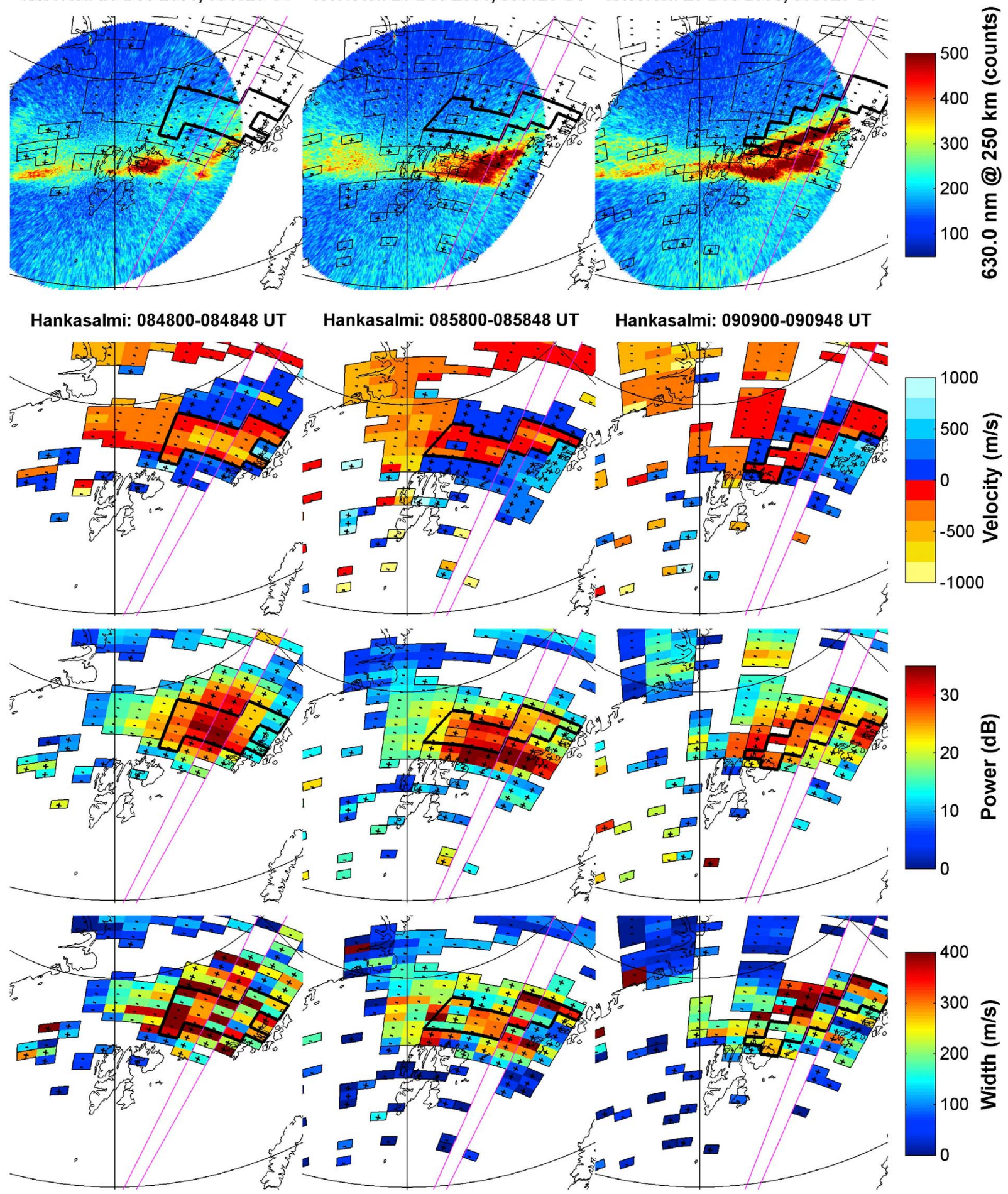

Figure 3. Projected all-sky images and SuperDARN Hankasalmi HF radar data for the three events at 08:48, 08:58 and 09:09 UT. The data are plotted in a magnetic grid with noon downward. The top row shows the intensity of the $630 \mathrm{~nm}$ aurora from the UiO imager in Ny-Ålesund, projected to an assumed emission altitude of $250 \mathrm{~km}$. The bottom three rows show data (line-of-sight Doppler velocity, backscatter power, and spectral width) from one scan of the Hankasalmi radar. In all columns the location of the RFE flow channel is indicated with a solid black line. Plus and minus symbols indicate range gates where the line-of-sight Doppler velocity was positive (toward the radar) and negative (away from the radar), respectively. All three examples show that the RFE flow channel is a distinct feature embedded within the background flow, in an area of generally enhanced backscatter power and broad Doppler spectral width. Pink guide lines indicate beam 13, which is presented in Figure 4. 

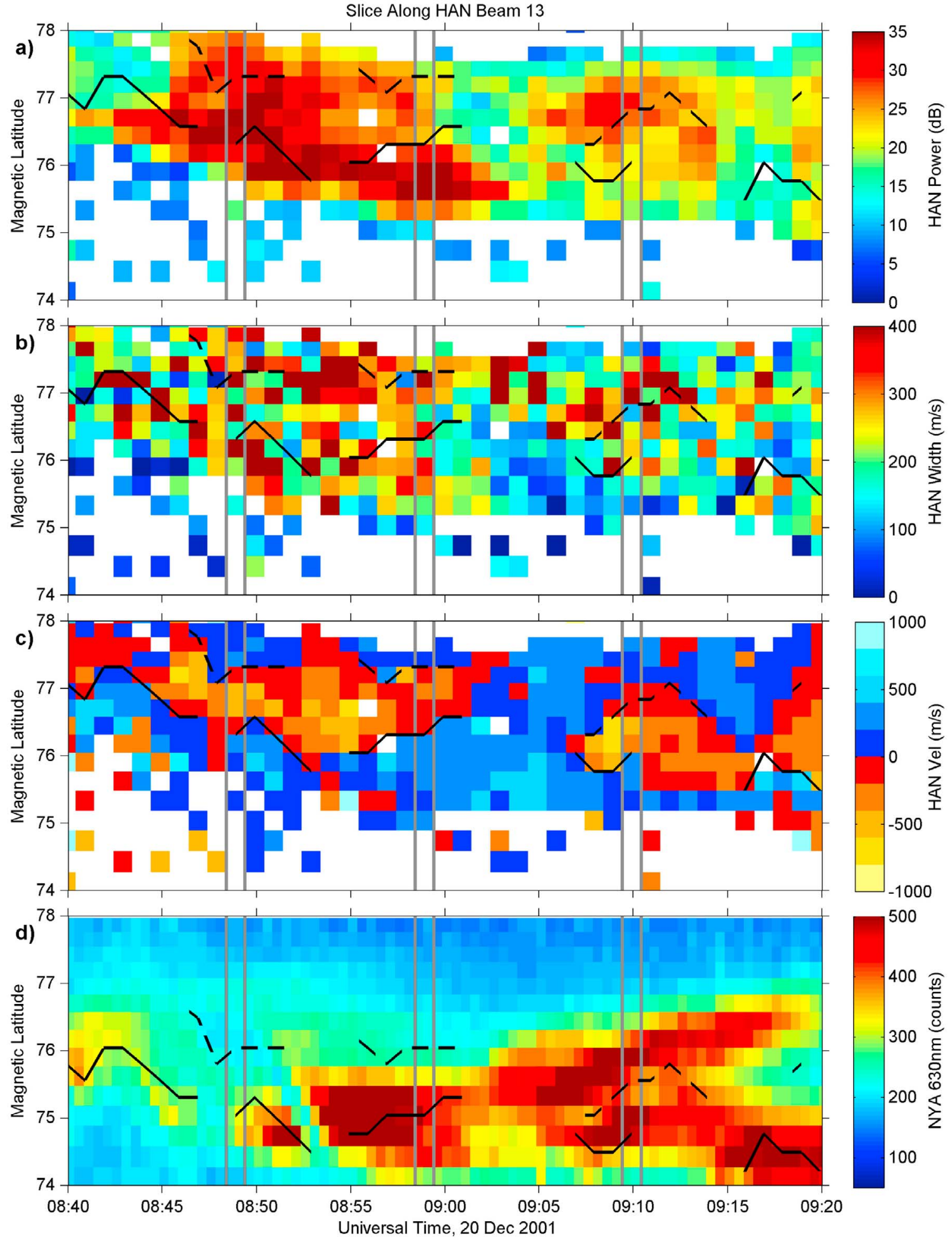

Figure 4. Keogram along beam 13 of the SuperDARN Hankasalmi HF radar of (a) backscatter power, (b) spectral width, (c) line-of-sight Doppler velocity, and (d) $630 \mathrm{~nm}$ auroral intensity. Indicated with vertical shaded guide lines are the three RFE events shown in Figure 3. Overlaid in all panels are solid black lines that indicate the border between negative and positive flow velocities (i.e., clockwise vorticity), and dashed black lines that indicate the border between positive and negative velocities (i.e., counterclockwise vorticity). Please note that in Figure 4d the lines have been offset by $140 \mathrm{~km}$, to align with the optical signatures. This example shows that the clockwise vorticity aligns with areas where there are upward Birkeland currents (i.e., intense aurora), and the counterclockwise vorticity aligns with areas where the aurora is faint. 
[12] In Figure 4a we note that the flow shears are often associated with the enhancement of backscatter power. At 08:45-09:00 UT, the RFE channel was in an area of constant high backscatter power $(>30 \mathrm{~dB})$. The highest backscatter power was seen near the flow shear of the equatorward border of the RFE (i.e., within 2-3 range cells of the solid black line). There was also high backscatter power $(>25 \mathrm{~dB})$ near the poleward border of the RFE from 08:45 to 09:00 and 09:08-09:15 UT (i.e., within 2-3 range cells of the dashed black line). The flow shears were also characterized by wide Doppler spectra. In Figure $4 \mathrm{~b}$ we notice that the equatorward border of the RFE was coincident with wide Doppler spectra (>300 m/s) at 08:40-09:00, around 09:10, and around 09:16 UT (i.e., along the solid black line). We also notice that the spectra were wide along the poleward border of the RFE at 08:47-09:02 UT and at 09:08-09:13 UT (i.e., along the dashed black line). Away from the solid or dashed black guide lines the spectra were generally less wide. The area of high backscatter power and wide spectra from 08:45 to 09:03 UT (i.e., the first two RFEs) may be remnants of earlier or ongoing irregularity formation. But from 09:06 to 09:12 UT a new flow channel (i.e., the last RFE) developed very quickly, and it expanded eastward into a previously undisturbed region, accompanied by an immediate increase in both spectral width and backscatter power from a low background level.

[13] The intensity of the $630 \mathrm{~nm}$ aurora from the UiO imager in Ny-Ålesund is shown in Figure 4d. We can now use our accumulated knowledge of flow vorticity and Birkeland Current Arcs (BCAs) [e.g., Oksavik et al., 2004b, 2005; Moen et al., 2008] to identify where the flow channel must be located relative to the aurora. The clockwise vorticity is consistent with an upward Birkeland current (i.e., intense aurora), so the RFE channel must have developed on the poleward side of a discrete auroral form. In Figure $4 d$ we have therefore shifted the two guide lines equatorward by $140 \mathrm{~km}$ so that they align with auroral signatures (see section 3.2 for a discussion of why $140 \mathrm{~km}$ was chosen). At $08: 40$ 08:46, 08:49-08:52, 08:55-09:01, 09:07-09:10, and 09:1609:20 UT we see that the clockwise vorticity (solid line) aligns very well with distinct enhancements in the $630 \mathrm{~nm}$ aurora. At 08:47-08:52, 08:55-09:01, 09:07-09:14, and 09:18-09:20 UT the counterclockwise vorticity (dashed line) aligns very well with a faint $630 \mathrm{~nm}$ aurora. Neither the auroral form nor the RFE propagated significantly poleward during their lifetime. The RFE disappeared when the bright arc faded around 09:02 UT, and it reappeared when the aurora intensified around 09:07 UT. At 09:14 UT the patch of high backscatter power drifted westward and into the polar cap (the sequence of radar scans is not shown).

[14] To summarize we note the following: (1) The RFE channel was located on the poleward side of, and aligned with, a discrete auroral form; (2) the RFE channel was located in a region of high backscatter power; (3) the spectral width was enhanced along the boundaries of the RFE channel; and (4) the optical data show that the standard SuperDARN range finding algorithm overestimated the ground range of the backscatter by $140 \mathrm{~km}$ on average. This radar range adjustment is consistent with the understanding that the plasma velocity shear boundary: (1) Excites optical emissions by the boundary current sheet carriers on the upgoing current side, (2) generates scattering irregularities, and (3) broadens the Doppler velocity spread.

\section{Discussion}

\subsection{First RFE Channel Seen by a SuperDARN HF Radar}

[15] In recent years we have published a series of papers documenting narrow flow channels seen by the EISCAT Svalbard Radar [e.g., Oksavik et al., 2004b, 2005] and Reversed Flow Events (RFEs) [Rinne et al., 2007; Moen et al., 2008]. The RFE is a common phenomenon near magnetic noon, and, within one hour of magnetic noon, it is seen up to $40 \%$ of the time in high-resolution EISCAT Svalbard Radar measurements [Rinne et al., 2007]. According to the definition of Rinne et al. [2007], the flow speed inside a RFE channel must be $>250 \mathrm{~m} / \mathrm{s}$ in the opposite direction of the background convection for an event to qualify as an RFE. Moen et al. [2008] showed that the RFE is a feature that can persist for 10-20 min. Until recently it was thought that these features were too small to be detected by SuperDARN HF radars [e.g., Oksavik et al., 2005]. But in the current paper we have for the first time documented several clear cases of RFE channels seen in SuperDARN HF radar data (see Figure 3).

[16] Transient phenomena in the cusp region have been studied for a while. In the SuperDARN community there have been many reports of poleward-moving transients in the dayside aurora [e.g., Milan et al., 1999, 2000; Thorolfsson et al., 2000; Moen et al., 2000]. Flow events in HF radar backscatter have been grouped into the following categories depending on their unique characteristics: Flow channel events (FCE) [Pinnock et al., 1993, 1995; Chisham et al., 2000; Neudegg et al., 1999, 2000], pulsed ionospheric flows (PIFs) [Provan et al., 1998, 2002; Provan and Yeoman, 1999; McWilliams et al., 2000], and polewardmoving radar auroral forms (PMRAFs) [Milan et al., 2000; Davies et al., 2002; Rae et al., 2004]. These features are often related to each other [Wild et al., 2001], and they all give enhanced flow in the same direction as the classical large-scale flow pattern in the polar cap. The observed flow channels in Figure 3 do not fit into any of these categories, because the enhanced flow is in the opposite direction of the background convection. As described by Rinne et al. [2007], RFEs are longitudinally elongated flow channels that oppose the large-scale background flow in the cusp region, and occur where the flow speed inside the channel is $>250 \mathrm{~m} / \mathrm{s}$. The observed flow channels in Figure 3 belong to this new category. To our knowledge, the current paper is the first identification of such RFEs seen by SuperDARN HF radars.

\subsection{Determination of the HF Backscatter Location}

[17] Before we can compare radar and optical signatures we need to discuss the location of the HF backscatter. The standard technique used by SuperDARN to determine the ground range is associated with uncertainty, because we do not know the meridional electron density profile and the exact path of the radio wave through the ionosphere [Villain et al., 1985]. Rodger et al. [1995] noticed an offset of up to $1^{\circ}$ in latitude between HF radar and optical features, without investigating why this offset was seen. Yeoman et al. [2001] carried out a detailed analysis using the SuperDARN 
pykkvibær radar in Iceland to detect artificial irregularities generated by the EISCAT Tromsø Heater. They found that the standard algorithm for backscatter range location is only accurate to within $114 \pm 15 \mathrm{~km}$ for $1.5 \mathrm{~F}$ mode backscatter. Yeoman et al. [2008] repeated this study and also included the SuperDARN Hankasalmi radar and artificial irregularities generated by the Space Plasma Exploration by Active Radar (SPEAR) facility in Svalbard. They discovered that the standard algorithm produced an error of around $165 \mathrm{~km}$ for 1.5F mode backscatter, and Yeoman et al. [2008] pointed out that this error is probably a function of both seasonal and solar cycle effects. Chisham et al. [2008] studied 5 years of backscatter elevation angle data from the SuperDARN Saskatoon radar, and they came to a similar conclusion; the standard technique places $1.5 \mathrm{~F}$ mode backscatter $\sim 150 \mathrm{~km}$ too far from the radar site. If we consider our range cell resolution of $45 \mathrm{~km}$ as a measure of our uncertainty, the $140 \pm 45 \mathrm{~km}$ offset we found in Figure 4 is therefore fully consistent with these studies. A new empirical virtual height model was recently developed by Chisham et al. [2008] with the goal of providing more accurate mapping of the locations of backscatter targets. For $1.5 \mathrm{~F}$ mode backscatter this new technique offers an average accuracy of better than $\pm 60 \mathrm{~km}$ [Yeoman et al., 2008]. We did not use the Chisham et al. [2008] technique here because it is not yet adopted as a standard SuperDARN technique, but we are of the opinion that the range determination could be significantly improved if the Chisham et al. [2008] technique is implemented as the new standard.

[18] The current study also allows us to go one step further and relate specific signatures in the SuperDARN HF radar data, like the vorticity and flow shear around a narrow RFE flow channel, to distinct optical signatures seen by an all-sky imager. In recent years we have gained substantial experience from the EISCAT Svalbard Radar and all-sky imagers of how auroral forms relate to these mesoscale flow channels in the cusp ionosphere [e.g., Oksavik et al., 2004b, 2005; Rinne et al., 2007; Moen et al., 2008]. It provides an alternative way of testing the accuracy of the standard SuperDARN ground range determination technique, without knowing anything about the meridional electron density profile. When we have a distinct auroral arc, like the one at 08:40-08:45 UT in Figure 4d, it must align with the flow shear indicated with the solid black line in Figure 4c, because this flow shear is indicative of clockwise vorticity, an upward Birkeland current, and enhanced precipitation of auroral electrons. On close inspection of Figure 4d, we also notice that the error in HF backscatter ground range may vary with time, for example, around 08:42 UT it is close to $120 \mathrm{~km}$, and at 08:46 UT it is close to $170 \mathrm{~km}$. However, $140 \mathrm{~km}$ appears to be a suitable average. Because all-sky imagers have such a wide 2-D field of view, we also have the opportunity to study how the accuracy varies with range away from the radar, that is, not just in a single point along each radar beam. For example, in Figure $4 \mathrm{~d}$ around 09:08 UT the dashed black line appears to be "spot on" in the area of weaker aurora (i.e., at $75.0^{\circ}$ latitude the offset appears to be $140 \mathrm{~km}$ ), while at $74.5^{\circ}$ latitude the solid black line appears to be $20 \mathrm{~km}$ south of the bright aurora (i.e., closer to a $120 \mathrm{~km}$ offset). This would have to be examined closely in future studies. The intense aurora poleward of the dashed line (09:05-09:15 UT) appears to be an artifact caused by the projection of the fisheye all-sky image onto a flat surface. A tall ray of bright aurora (e.g., extending along the field line from 150 to $500 \mathrm{~km}$ altitude) will be stretched across the projected image, and, due to geometry, it will appear as a straight line pointing toward the imager site in Ny-Ålesund, which is also seen in the top right frame of Figure 3.

[19] We can now look at how the HF backscatter power develops in association with the RFE flow disturbance, which Moen et al. [2008] interpreted as a BCA phenomenon. In Figure 4c, the RFE channel developed in phase with intensifications of the aurora. The BCA (Figure 4d) was located on the equatorward edge of the RFE channel (Figure 4c), consistent with a converging electric field and an upward field-aligned current [Oksavik et al., 2004b, 2005; Moen et al., 2008]. In this case, when IMF $B_{Z}<0$, we conclude that the $630 \mathrm{~nm}$ equatorward boundary represents a proxy for the open-closed boundary [Moen et al., 1996, 1998].

\subsection{Formation of Plasma Irregularities Via Flow Shears}

[20] In Figure 4 we notice that there was substantial enhancement of backscatter power associated with the RFE. On the edges of the RFE there will be strong flow shears that are unstable to $\mathrm{KH}$ structuring of the plasma into hectometer scales [Carlson et al., 2008]. Gondarenko and Guzdar [2004] derived from nonlinear modeling of the high-latitude ionosphere that GD instability would generate structures in $10 \mathrm{~km}$ to $100 \mathrm{~m}$ scales, but typical GD growth times of $>10 \mathrm{~min}$ [e. g., Moen et al., 2002] are too slow to explain our rapid structuring observations (e.g., Figure 4 around 09:06 UT when a patch of enhanced backscatter power appeared in less than 1-2 min). Keskinen et al. [1988] concluded from linear theory that the maximum $\mathrm{KH}$ growth rate $\gamma$ in the $F$ region is given by $\gamma=c(\Delta V / L)$, where $\Delta V$ is the velocity shear. By assuming that the density does not change over the velocity scale length $L$, they obtained a value for the coefficient $c=0.19$. Keskinen et al. [1988] also noted that the growth rate was reduced if they included in their simulations a density gradient across the velocity shear or Pedersen conductivity coupling (i.e., ion collisions). In the rapid growth phase from 09:06-09:12 UT, the high backscatter power developed in a region void of precipitation (i.e., dashed line in Figures $4 \mathrm{a}$ and $4 \mathrm{~d}$ ). Consequently, we have no reduction in growth rate there due to $\mathrm{BCA}$ precipitation. Moen et al. [2008] suggested that the RFE-BCA phenomenon is a feature of MI coupling in the poorly conducting winter cusp ionosphere.

[21] Now we apply the theory of Keskinen et al. [1988] to our line-of-sight Doppler velocities $V_{\text {LOS }}$ from the Hankasalmi beam 13 (i.e., the data shown in Figure 4c). To calculate velocity shears $\Delta V$ we use the velocity difference between two neighboring range gates $r_{1}$ and $r_{2}$; that is, $\Delta V=$ $\left|V\left(r_{2}\right)-V\left(r_{1}\right)\right|$. Figure 5a shows the distribution of velocity shears $\Delta V_{\text {LOS }}$. The occurrence peaks at small values, but we also notice that there is a significant tail of large velocity shears. In Figure 5b we calculate the KH growth times. For the solid line we have used $L=45 \mathrm{~km}$ (i.e., one range gate) and the observed line-of-sight velocity shear $\Delta V_{\text {LOS. For }}$ 


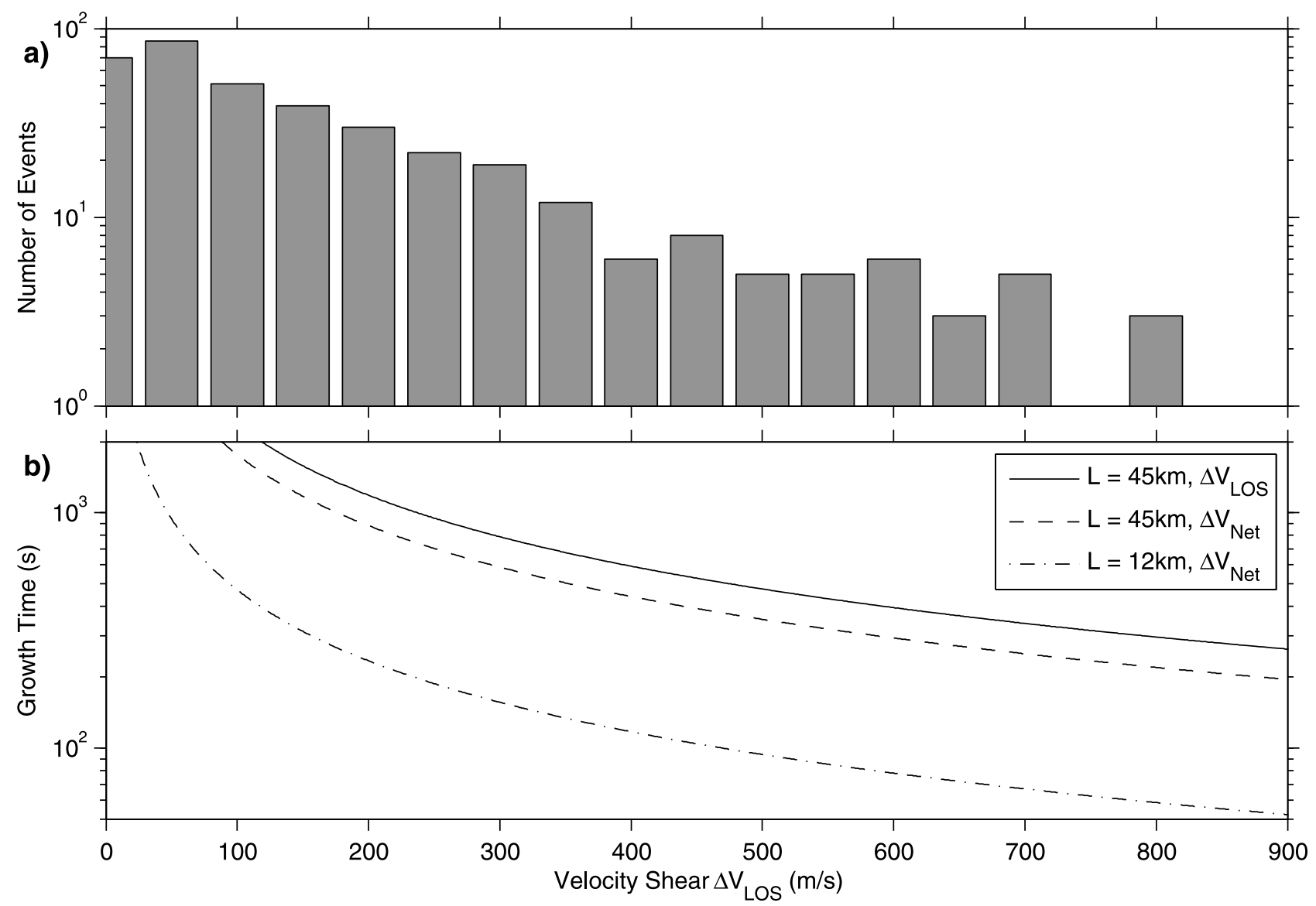

Figure 5. A closer inspection of the line-of-sight velocity shear data and estimated KH instability growth times along beam 13 of the SuperDARN Hankasalmi HF radar. (a) The occurrence of line-of-sight velocity shears $\Delta V_{\text {LOS }}$ in the time interval 08:40-09:20 UT and 74 $-78^{\circ}$ magnetic latitude. (b) Calculated KH instability growth times as a function of velocity shear for three cases: (1; solid line) Using the lineof-sight velocity shear and $45 \mathrm{~km}$ spatial scale, (2; dashed line) using the net velocity shear and $45 \mathrm{~km}$ spatial scale, and (3; dot-dashed line) using the net velocity shear and $12 \mathrm{~km}$ spatial scale.

$\Delta V_{\text {LOS }}=800 \mathrm{~m} / \mathrm{s}$ we get a growth time of $\sim 300 \mathrm{~s}$. We get the dashed line if we consider the $42^{\circ}$ angle between the radar beam and the large-scale flow direction, that is, we use the net velocity $\Delta V_{\text {Net }}$. Here the growth time at $\Delta V_{\text {LOS }}=$ $800 \mathrm{~m} / \mathrm{s}$ has decreased to $\sim 200 \mathrm{~s}$. In the previous two examples we have used a scale length of one $45 \mathrm{~km}$ range gate, but, in principle, the scale length could be much smaller. For example, Rinne et al. [2007] presented EISCAT data of flow shears where the scale length was one ESR beam wide, that is, $L=12 \mathrm{~km}$. Applying that scale length we get the dot-dashed line (Figure $5 \mathrm{~b}$ ), and we notice that the growth time at $\Delta V_{\mathrm{LOS}}=800 \mathrm{~m} / \mathrm{s}$ has decreased to $\sim 60 \mathrm{~s}$. We also notice that all $\Delta V_{\text {LOS }}>500 \mathrm{~m} / \mathrm{s}$ give growth times less than $100 \mathrm{~s}$. Theory still needs to address the rapid cascade from the $100 \mathrm{~m}$ scale sizes modeled and the $10 \mathrm{~m}$ scale sizes observed, but these data should be valuable guidance for that purpose. These findings are consistent with the two-step process of Carlson et al. [2007, 2008], that the KH instability can be an important process to generate large amplitude seed irregularities on which the GD instability [e.g., Gondarenko and Guzdar, 2004] can feed downstream in the polar cap at its own growth rate and produce structure down to decameter irregularities, and explain $10 \mathrm{~m}$ scales, if theory is extended to shorter scales.

\section{Summary and Concluding Remarks}

[22] In the current paper we have for the first time documented several clear cases of RFE channels in SuperDARN $\mathrm{HF}$ radar data. Using our prior experience from the EISCAT Svalbard Radar [e.g., Oksavik et al., 2004b, 2005; Rinne et al., 2007; Moen et al., 2008] we were also able to make an estimate of the ground range of the SuperDARN HF radar echoes, because a distinct auroral arc must align with the flow shear of clockwise vorticity (i.e., the upward Birkeland current due to enhanced precipitation of auroral electrons). For the interval of interest, we found that the standard algorithm overestimated the ground range of the SuperDARN HF radar echoes by $140 \pm 45 \mathrm{~km}$.

[23] We have also demonstrated that RFEs should be an important process for the formation of plasma irregularities, which are known to cause severe space weather effects like scintillation and disturbance of ground-to-satellite links and communication and GPS navigation systems [e.g., Basu et al., 1988, 1990, 1998]. Having identified what RFE 
channels look like in SuperDARN HF radar data, the huge data set (more than one decade of SuperDARN HF radar data) now opens a completely new world to understanding both the large-scale characteristics of RFEs and flow channels and how plasma instabilities operate in the cusp region more generally. The flow shears of RFEs were associated with wide Doppler spectra and may cause a rapid development of shear driven instabilities. Several times there was an immediate response in enhanced backscatter power, which implies rapid development of decameter irregularities within the one minute resolution of the radar scan; that is, much faster than anticipated from the gradient drift (GD) instability alone. However, the cusp ionosphere is a complex region and other modes of instability growth cannot be ruled out. The current convective instability [Ossakow and Chaturvedi, 1979; Chaturvedi and Ossakow, 1981; Tsunoda, 1988] may also be relevant, depending on how large the associated currents are. The combination of ground and in situ sounding rocket measurements will also be needed to parameterize the different modes with realistic values down to the scale sizes that apply [Moen et al., 2002].

[24] Acknowledgments. We thank the ACE MAG instrument team and the ACE Science Center for providing the ACE data. SuperDARN HF radar operations at the University of Leicester are supported by STFC grant PP/E007929/1, and M.L. is funded by STFC grant ST/H002480/1. This project has also been sponsored by the Research Council of Norway, the Air Force Office of Scientific Research, Air Force Material Command, USAF, under grant FA8655-10-1-3003, and COST action ES0803. Support is also acknowledged to the USTAR program.

[25] Robert Lysak thanks the reviewers for their assistance in evaluating this paper.

\section{References}

Baker, K. B., R. A. Greenwald, J. M. Ruohoniemi, J. R. Dudeney, M. Pinnock, P. T. Newell, M. E. Greenspan, and C.-I. Meng (1990), Simultaneous HF-radar and DMSP observations of the cusp, Geophys. Res. Lett., 17(11), 1869-1872, doi:10.1029/GL017i011p01869.

Basu, S., S. Basu, E. MacKenzie, P. F. Fougere, W. R. Coley, N. C. Maynard, J. D. Winningham, M. Sugiura, W. B. Hanson, and W. R. Hoegy (1988), Simultaneous density and electric field fluctuation spectra associated with velocity shears in the auroral oval, J. Geophys. Res., 93(A1), 115-136, doi:10.1029/JA093iA01p00115.

Basu, S., S. Basu, E. MacKenzie, W. R. Coley, J. R. Sharber, and W. R. Hoegy (1990), Plasma structuring by the gradient drift instability at high latitudes and comparison with velocity shear driven processes, J. Geophys. Res., 95(A6), 7799-7818, doi:10.1029/JA095iA06p07799.

Basu, S., S. Basu, P. K. Chaturvedi, and C. M. Bryant Jr. (1994), Irregularity structures in the cusp/cleft and polar cap regions, Radio Sci., 29(1), 195-207, doi:10.1029/93RS01515.

Basu, S., E. J. Weber, T. W. Bullett, M. J. Keskinen, E. MacKenzie, P. Doherty, R. Sheehan, H. Kuenzler, P. Ning, and J. Bongiolatti (1998), Characteristics of plasma structuring in the cusp/cleft region at Svalbard, Radio Sci., 33(6), 1885-1899, doi:10.1029/98RS01597.

Carlson, H. C., Jr., K. Oksavik, J. Moen, and T. Pedersen (2004), Ionospheric patch formation: Direct measurements of the origin of a polar cap patch, Geophys. Res. Lett., 31, L08806, doi:10.1029/2003GL018166.

Carlson, H. C., T. Pedersen, S. Basu, M. Keskinen, and J. Moen (2007), Case for a new process, not mechanism, for cusp irregularity production, J. Geophys. Res., 112, A11304, doi:10.1029/2007JA012384.

Carlson, H. C., K. Oksavik, and J. Moen (2008), On a new process for cusp irregularity production, Ann. Geophys., 26, 2871-2885, doi:10.5194/ angeo-26-2871-2008.

Chaturvedi, P. K., and S. L. Ossakow (1981), The current convective instability as applied to the auroral ionosphere, J. Geophys. Res., 86(A6), 4811-4814, doi:10.1029/JA086iA06p04811.

Chisham, G., M. Pinnock, and A. S. Rodger (2000), Poleward-moving HF radar flow bursts in the cusp: Transient changes in flow speed or direction?, Geophys. Res. Lett., 27(7), 919-922, doi:10.1029/1999GL010760.

Chisham, G., et al. (2007), A decade of the Super Dual Auroral Radar Network (SuperDARN): Scientific achievements, new techniques and future directions, Surv. Geophys., 28(1), 33-109, doi:10.1007/s10712-007-9017-8.
Chisham, G., T. K. Yeoman, and G. J. Sofko (2008), Mapping ionospheric backscatter measured by the SuperDARN HF radars-Part 1: A new empirical virtual height model, Ann. Geophys., 26, 823-841, doi:10.5194/ angeo-26-823-2008.

Cowley, S. W. H., and M. Lockwood (1992), Excitation and decay of solar wind-driven flows in the magnetosphere-ionosphere system, Ann. Geophys., 10, 103-115.

Cowley, S. W. H., J. P. Morelli, and M. Lockwood (1991), Dependence of convective flows and particle precipitation in the high-latitude dayside ionosphere on the $X$ and $Y$ components of the interplanetary magnetic field, J. Geophys. Res., 96(A4), 5557-5564, doi:10.1029/90JA02063.

Davies, J. A., T. K. Yeoman, I. J. Rae, S. E. Milan, M. Lester, M. Lockwood, and A. McWilliams (2002), Ground-based observations of the auroral zone and polar cap ionospheric responses to dayside transient reconnection, Ann. Geophys., 20, 781-794, doi:10.5194/angeo-20-781-2002.

Denig, W. F., W. J. Burke, N. C. Maynard, F. J. Rich, B. Jacobsen, P. E. Sandholt, A. Egeland, S. Leontjev, and V. G. Vorobjev (1993), Ionospheric signatures of dayside magnetopause transients: A case study using satellite and ground measurements, J. Geophys. Res., 98(A4), 5969-5980, doi:10.1029/92JA01541.

Farrugia, C. J., et al. (2004), Pulsed flows at the high-altitude cusp poleward boundary, and associated ionospheric convection and particle signatures, during a Cluster-FAST-SuperDARN-Søndrestrøm conjunction under a southwest IMF, Ann. Geophys., 22, 2891-2905, doi:10.5194/angeo-222891-2004.

Glassmeier, K.-H., and M. Stellmacher (1996), Mapping flux transfer events to the ionosphere, Adv. Space Res., 18(8), 151-160, doi:10.1016/ 0273-1177(95)00983-3.

Goertz, C. K., E. Nielsen, A. Korth, K. H. Glassmeier, C. Haldoupis, P. Hoeg, and D. Hayward (1985), Observations of a possible ground signature of flux transfer events, J. Geophys. Res., 90(A5), 4069-4078, doi:10.1029/JA090iA05p04069.

Gondarenko, N. A., and P. N. Guzdar (2004), Plasma patch structuring by the nonlinear evolution of the gradient drift instability in the high-latitude ionosphere, J. Geophys. Res., 109, A09301, doi:10.1029/2004JA010504.

Haerendel, G., G. Paschmann, N. Sckopke, H. Rosenbauer, and P. C. Hedgecock (1978), The frontside boundary layer of the magnetosphere and the problem of reconnection, J. Geophys. Res., 83(A7), 3195-3216, doi:10.1029/JA083iA07p03195.

Keskinen, M. J., and S. L. Ossakow (1983), Theories of high-latitude ionospheric irregularities: A review, Radio Sci., 18(6), 1077-1091, doi:10.1029/RS018i006p01077.

Keskinen, M. J., H. G. Mitchell, J. A. Fedder, P. Satyanarayana, S. T. Zalesak, and J. D. Huba (1988), Nonlinear evolution of the KelvinHelmholtz instability in the high-latitude ionosphere, J. Geophys. Res., 93(A1), 137-152, doi:10.1029/JA093iA01p00137.

Lockwood, M., J. Moen, S. W. H. Cowley, A. D. Farmer, U. P. Løvhaug, H. Lühr, and V. N. Davda (1993), Variability of dayside convection and motions of the cusp/cleft aurora, Geophys. Res. Lett., 20(11), 1011-1014, doi:10.1029/93GL00846.

Lockwood, M., S. W. H. Cowley, M. F. Smith, R. P. Rijnbeek, and R. C. Elphic (1995), The contribution of flux transfer events to convection, Geophys. Res. Lett., 22(10), 1185-1188, doi:10.1029/95GL01008.

McWilliams, K. A., T. K. Yeoman, and G. Provan (2000), A statistical survey of dayside pulsed ionospheric flows as seen by the CUTLASS Finland HF radar, Ann. Geophys., 18, 445-453, doi:10.1007/s00585-000-0445-8.

Milan, S. E., T. K. Yeoman, and M. Lester (1998), The dayside auroral zone as a hard target for coherent HF radars, Geophys. Res. Lett., 25(19), 3717-3720, doi:10.1029/98GL02781.

Milan, S. E., M. Lester, S. W. H. Cowley, J. Moen, P. E. Sandholt, and C. J. Owen (1999), Meridian-scanning photometer, coherent HF radar, and magnetometer observations of the cusp: A case study, Ann. Geophys. 17, 159-172, doi:10.1007/s00585-999-0159-5.

Milan, S. E., M. Lester, S. W. H. Cowley, and M. Brittnacher (2000), Convection and auroral response to a southward turning of the IMF: Polar UVI, CUTLASS, and IMAGE signatures of transient magnetic flux transfer at the magnetopause, J. Geophys. Res., 105(A7), 15,741-15,755, doi:10.1029/2000JA900022.

Moen, J., P. E. Sandholt, M. Lockwood, W. F. Denig, U. P. Løvhaug, B. Lybekk, A. Egeland, D. Opsvik, and E. Friis-Christensen (1995), Events of enhanced convection and related dayside auroral activity, J. Geophys. Res., 100(A12), 23,917-23,934, doi:10.1029/95JA02585.

Moen, J., D. Evans, H. C. Carlson, and M. Lockwood (1996), Dayside moving auroral transients related to LLBL dynamics, Geophys. Res. Lett., 23(22), 3247-3250, doi:10.1029/96GL02766.

Moen, J., D. A. Lorentzen, and F. Sigernes (1998), Dayside moving auroral forms and bursty proton auroral events in relation to particle boundaries observed by NOAA 12, J. Geophys. Res., 103(A7), 14,855-14,863, doi:10.1029/97JA02877. 
Moen, J., H. C. Carlson, S. E. Milan, N. Shumilov, B. Lybekk, P. E. Sandholt, and M. Lester (2000), On the collocation between dayside auroral activity and coherent HF radar backscatter, Ann. Geophys., 18, 1531-1549, doi:10.1007/s00585-001-1531-2.

Moen, J., I. K. Walker, L. Kersley, and S. E. Milan (2002), On the generation of cusp HF backscatter irregularities, J. Geophys. Res., 107(A4) 1044, doi:10.1029/2001JA000111.

Moen, J., H. C. Carlson, K. Oksavik, C. P. Nielsen, S. E. Pryse, H. R. Middleton, I. W. McCrea, and P. Gallop (2006), EISCAT observations of plasma patches at sub-auroral cusp latitudes, Ann. Geophys., 24, 2363-2374, doi:10.5194/angeo-24-2363-2006.

Moen, J., Y. Rinne, H. C. Carlson, K. Oksavik, R. Fujii, and H. Opgenoorth (2008), On the relationship between thin Birkeland current arcs and reversed flow channels in the winter cusp/cleft ionosphere, J. Geophys. Res., 113, A09220, doi:10.1029/2008JA013061.

Neudegg, D. A., T. K. Yeoman, S. W. H. Cowley, G. Provan, G. Haerendel, W. Baumjohann, U. Auster, K.-H. Fornacon, E. Georgescu, and C. J. Owen (1999), A flux transfer event observed at the magnetopause by the Equator-S spacecraft and in the ionosphere by the CUTLASS HF radar, Ann. Geophys., 17, 707-711, doi:10.1007/s00585-999-0707-z.

Neudegg, D. A., et al. (2000), A survey of magnetopause FTEs and associated flow bursts in the polar ionosphere, Ann. Geophys., 18, 416-435, doi: $10.1007 / \mathrm{s} 00585-000-0416-0$.

Newell, P. T., J. M. Ruohoniemi, and C.-I. Meng (2004), Maps of precipitation by source region, binned by IMF, with inertial convection streamlines, J. Geophys. Res., 109, A10206, doi:10.1029/2004JA010499.

Ossakow, S. L., and P. K. Chaturvedi (1979), Current convective instability in the diffuse aurora, Geophys. Res. Lett., 6(4), 332-334, doi:10.1029/ GL006i004p00332.

Oksavik, K., F. Søraas, J. Moen, R. Pfaff, J. A. Davies, and M. Lester (2004a), Simultaneous optical, CUTLASS HF radar, and FAST spacecraft observations: Signatures of boundary layer processes in the cusp, Ann. Geophys., 22, 511-525, doi:10.5194/angeo-22-511-2004.

Oksavik, K., J. Moen, and H. C. Carlson (2004b), High-resolution observations of the small-scale flow pattern associated with a poleward moving auroral form in the cusp, Geophys. Res. Lett., 31, L11807, doi:10.1029/ 2004GL019838.

Oksavik, K., J. Moen, H. C. Carlson, R. A. Greenwald, S. E. Milan, M. Lester, W. F. Denig, and R. J. Barnes (2005), Multi-instrument mapping of the small-scale flow dynamics related to a cusp auroral transient, Ann. Geophys., 23, 2657-2670, doi:10.5194/angeo-23-2657-2005.

Pinnock, M., A. S. Rodger, J. R. Dudeney, K. B. Baker, P. T. Newell, R. A. Greenwald, and M. E. Greenspan (1993), Observations of an enhanced convection channel in the cusp ionosphere, J. Geophys. Res., 98(A3), 3767-3776, doi:10.1029/92JA01382.

Pinnock, M., A. S. Rodger, J. R. Dudeney, F. Rich, and K. B. Baker (1995), High spatial and temporal resolution observations of the ionospheric cusp, Ann. Geophys., 13, 919-925, doi:10.1007/s00585-995-0919-9.

Provan, G., and T. K. Yeoman (1999), Statistical observations of the MLT, latitude and size of pulsed ionospheric flows with the CUTLASS Finland radar, Ann. Geophys., 17, 855-867, doi:10.1007/s00585-999-0855-1.

Provan, G., T. K. Yeoman, and S. E. Milan (1998), CUTLASS Finland radar observations of the ionospheric signatures of flux transfer events and the resulting plasma flows, Ann. Geophys., 16, 1411-1422, doi:10.1007/s00585-998-1411-0.

Provan, G., S. E. Milan, M. Lester, T. K. Yeoman, and H. Khan (2002), Simultaneous observations of the ionospheric footprint of flux transfer events and dispersed ion signatures, Ann. Geophys., 20, 281-287, doi:10.5194/angeo-20-281-2002.

Rae, I. J., F. R. Fenrich, M. Lester, K. A. McWilliams, and J. D. Scudder (2004), Solar wind modulation of cusp particle signatures and their associated ionospheric flows, J. Geophys. Res., 109, A03223, doi:10.1029/ 2003JA010188

Rinne, Y., J. Moen, K. Oksavik, and H. C. Carlson (2007), Reversed flow events in the winter cusp ionosphere observed by the European Incoherent Scatter (EISCAT) Svalbard radar, J. Geophys. Res., 112, A10313, doi:10.1029/2007JA012366.

Rinne, Y., J. Moen, H. C. Carlson, and M. R. Hairston (2010), Stratification of east-west plasma flow channels observed in the ionospheric cusp in response to IMF $\mathrm{B}_{\mathrm{Y}}$ polarity changes, Geophys. Res. Lett., 37, L13102, doi:10.1029/2010GL043307.

Rodger, A. S., S. B. Mende, T. J. Rosenberg, and K. B. Baker (1995), Simultaneous optical and HF radar observations of the ionospheric cusp, Geophys. Res. Lett., 22(15), 2045-2048, doi:10.1029/95GL01797.

Ruohoniemi, J. M., and K. B. Baker (1998), Large-scale imaging of highlatitude convection with Super Dual Auroral Radar Network HF radar observations, J. Geophys. Res., 103(A9), 20,797-20,811, doi:10.1029/ 98JA01288.
Russell, C. T., and R. C. Elphic (1978), Initial ISEE magnetometer results: Magnetopause observations, Space Sci. Rev., 22, 681-715, doi:10.1007/ BF00212619.

Russell, C. T., and R. C. Elphic (1979), ISEE observations of flux transfer events at the dayside magnetopause, Geophys. Res. Lett., 6(1), 33-36, doi:10.1029/GL006i001p00033.

Sandholt, P. E., and C. J. Farrugia (2007), Role of poleward moving auroral forms in the dawn-dusk auroral precipitation asymmetries induced by IMF $B_{Y}, J$. Geophys. Res., 112, A04203, doi:10.1029/2006JA011952.

Sandholt, P. E., M. Lockwood, T. Oguti, S. W. H. Cowley, K. S. C. Freeman, B. Lybekk, A. Egeland, and D. M. Willis (1990), Midday auroral breakup events and related energy and momentum transfer from the magnetosheath, J. Geophys. Res., 95(A2), 1039-1060, doi:10.1029/ JA095iA02p01039.

Sandholt, P. E., J. Moen, D. Opsvik, W. F. Denig, and W. J. Burke (1993), Auroral event sequence at the dayside polar cap boundary: Signature of time-varying solar wind-magnetosphere-ionosphere coupling, Adv. Space Res., 13(4), 7-15, doi:10.1016/0273-1177(93)90305-U.

Sandholt, P. E., C. J. Farrugia, and W. F. Denig (2004), Detailed dayside auroral morphology as a function of local time for southeast IMF orientation: Implications for solar wind coupling, Ann. Geophys., 22, 3537-3560, doi:10.5194/angeo-22-3537-2004

Saunders, M. A., C. T. Russell, and N. Sckopke (1984), Flux transfer events: Scale size and interior structure, Geophys. Res. Lett., 11(2), 131-134, doi:10.1029/GL011i002p00131.

Southwood, D. J. (1985), Theoretical aspects of ionosphere-magnetospheresolar wind coupling, Adv. Space Res., 5(4), 7-14, doi:10.1016/0273-1177 (85)90110-3.

Southwood, D. J. (1987), The ionospheric signature of flux transfer events, J. Geophys. Res., 92(A4), 3207-3213, doi:10.1029/JA092iA04p03207.

Stern, D. (1984), Magnetospheric dynamo processes, in Magnetospheric Currents, Geophys. Monogr. Ser., vol. 28, edited by T. Potemra, pp. 200-207, AGU, Washington, D. C., doi:10.1029/GM028p0200.

Thorolfsson, A., J.-C. Cerisier, M. Lockwood, P. E. Sandholt, C. Senior, and M. Lester (2000), Simultaneous optical and radar signatures of poleward-moving auroral forms, Ann. Geophys., 18, 1054-1066, doi:10.1007/ s00585-000-1054-2.

Tsunoda, R. T. (1988), High-latitude $F$ region irregularities: A review and synthesis, Rev. Geophys., 26(4), 719-760, doi:10.1029/RG026i004p00719. van Eyken, A. P., H. Rishbeth, D. M. Willis, and S. W. H. Cowley (1984), Initial EISCAT observations of plasma convection at invariant latitudes 70-77 , J. Atmos. Terr. Phys., 46, 635-641, doi:10.1016/0021-9169(84) 90081-3.

Villain, J. P., G. Caudal, and C. Hanuise (1985), A Safari-Eiscat comparison between the velocity of $\mathrm{F}$ region small-scale irregularities and the ion drift, J. Geophys. Res., 90(A9), 8433-8443, doi:10.1029/JA090iA09p08433.

Wild, J. A., et al. (2001), First simultaneous observations of flux transfer events at the high-latitude magnetopause by the Cluster spacecraft and pulsed radar signatures in the conjugate ionosphere by the CUTLASS and EISCAT radars, Ann. Geophys., 19, 1491-1508, doi:10.5194/ angeo-19-1491-2001.

Yeoman, T. K., M. Lester, S. W. H. Cowley, S. E. Milan, J. Moen, and P. E. Sandholt (1997), Simultaneous observations of the cusp in optical, DMSP and HF radar data, Geophys. Res. Lett., 24(17), 2251-2254, doi:10.1029/97GL02072.

Yeoman, T. K., D. M. Wright, A. J. Stocker, and T. B. Jones (2001), An evaluation of range accuracy in the Super Dual Auroral Radar Network over-the-horizon HF radar systems, Radio Sci., 36(4), 801-813, doi:10.1029/2000RS002558.

Yeoman, T. K., G. Chisham, L. J. Baddeley, R. S. Dhillon, T. J. T. Karhunen, T. R. Robinson, A. Senior, and D. M. Wright (2008), Mapping ionospheric backscatter measured by the SuperDARN HF radars-Part 2: Assessing SuperDARN virtual height models, Ann. Geophys., 26, 843-852, doi:10.5194/angeo-26-843-2008.

H. C. Carlson, Space Weather Center, Center for Atmospheric and Space Sciences, Utah State University, 4405 Old Main Hill, Logan, UT 84322, USA.

M. Lester, Department of Physics and Astronomy, University of Leicester, Leicester LE1 7RH, UK.

J. I. Moen, The University Centre in Svalbard, POB 156, Longyearbyen NO-9171, Norway.

K. Oksavik, Department of Physics and Technology, University of Bergen, POB 7803, Bergen NO-5020, Norway. (kjellmar.oksavik@uib.no)

E. H. Rekaa, Department of Physics, University of Oslo, PB 1048, Blindern, Oslo NO-0316, Norway. 